61 Wright J, Friedrich W, Cinq-Mars C, Cyr M, McDuff F. Self-destructive and delinquent behaviors of adolescent female victims of child sexual abuse: rates and covariates in clinical and nonclinical samples. Violence and vict 2004; 19: 627-43.

62 Ystgaard M, Hestetun I, Loeb M, Mehlum L. Is there a specific relationship between childhood sexual and physical abuse and repeated suicidal behavior? Child Abuse Negl 2004; 28: 863-75.

63 Zanarini MC, Yong LMA, Frankenburg FR, Hennen J, Reich DB, Marino MF, Vjuanovic AA. Severity of reported childhood sexual abuse and its relation to severity of borderline psychopathology and psychosocial impairment among borderline inpatients. J Nerv Ment Dis 2002; 190: 381-7.

64 Zlotnick C, Shea MT, Pearlstein T, Simpson E, Costello E, Begin A. The relationship between dissociative symptoms, alexithymia, impulsivity, sexual abuse, and self-mutilation. Compr Psychiatry 1996; 37: 12-16.

65 Zoroglu SS, Tuzun U, Sar V, Tutkun H, Savas HA, Ozturk M, Alyanak B, Kora ME. Suicide attempt and self-mutilation among Turkish high schoo students in relation with abuse, neglect, and dissociation. Psychiatry Clin Neurosci 2003: 57: 119-26.

66 Zweig-Frank H, Paris J, Guzder J. Psychological risk factors for dissociation and self-mutilation in female patients with borderline personality disorder. Can J Psychiatry 1994; 39: 259-64.

67 Kraemer HC, Stice E, Kazdin A, Offord D, Kupfer D. How do risk factors work together? Mediators, moderators, and independent, overlapping, and proxy risk factors. Am J Psychiatry 2001; 158: 848-56.

68 Rind B, Tromovitch P, Bauserman R. A meta-analytic examination of assumed properties of child sexual abuse using college samples. Psychol Bull 1998; 124: $22-53$.

69 Klonsky ED, Muehlenkamp JJ. Self-injury: a research review for the practitioner. J Clin Psychol 2007; 63: 1045-

\title{
Maudsley Hospital nightmares
}

In his book, War Neurosis and Shell Shock (1919) Frederick Mott remarked on the importance of recurrent dreams whose content recalled combat experiences in the symptomatology of the psychological casualties of the Great War treated at the Maudsley. Here are two nightmares recalled by an infantry sergeant who had been a teacher in peacetime. The words in parentheses were added by Mott.

'I appeared to be resting on the roadside when a woman (unknown) called to me to see her husband's (a comrade) body which was about to be buried. I went to a field in which was a pit, and near the edge four or five dead bodies. In a hand cart near by was a legless body, the head of which was hidden by a slab of stone. (He had seen a legless body, which was covered with a Mackintosh sheet, which he removed). On moving the stone I found the body alive, and the head spoke to me, imploring me to see that it was not buried. Burial party arrived, and I was about to be buried with legless body when I awoke.

'After spending an evening with a brother (dead 11 years ago) I was making my way home when a violent storm compelled me to take shelter in a kind of culvert, which later turned into a quarry, situated between two houses. Men were doing blasting operations in the quarry, and whilst watching them I saw great upheavals of rock and eventually the building all around collapsed (explosion of a mine). Amongst the debris were several mutilated bodies, the most prominent of which was legless. I tried to proceed to get to the body, but found that I was myself pinned down by masonry which had fallen on top of me. As I struggled to get free the whole scene appeared to change to a huge fire, everything being enveloped in flames and through the flames I could still see the legless body which now bore the head of my wife, who was calling for me. I was struggling to get free when my mother seemed to be coming to my assistance, and I awoke to find the nurses and orderlies standing over me.'

Selected by Robert Howard, Professor of Old Age Psychiatry and Psychopathology, Institute of Psychiatry, King's College London 